Journal of Teacher Education for Sustainability, vol. 18, no. 2, pp. 66-74, 2016

\title{
Teacher Training Programs for Gifted Education with Focus on Sustainability
}

\author{
Eva Reid and Božena Horváthová \\ Constantine the Philosopher University in Nitra, Slovakia
}

\begin{abstract}
Scholars, psychologists, and teachers from around the world have been dealing with the topic of giftedness for many years. Also in Slovakia, development of giftedness is a highly topical issue and gifted education has earned its place in the current curricular documents issued by the Ministry of Education. The national curriculum specifies education objectives, teaching plans, requirements for personnel, organizational and materialtechnological requirements for gifted education. However, the personnel requirements are problematic not only in Slovakia, but also in other countries. Most attention is paid to identification and development of gifted children, but very little consideration is given to the training of teachers for gifted children. The lack of justifying teacher training does not guarantee sustainability of gifted education. The aim of this paper is to map and describe gifted education, teacher training programs and qualifications for teachers of intellectually gifted pupils in Slovakia, Austria, Belgium and Finland. These countries were chosen because of very different perceptions of the gifted education and teacher training. These systems are compared and a proposal for sustainable teacher training is offered.
\end{abstract}

Keywords: teacher training programs, sustainable gifted education

\section{Introduction}

Until recently the common assumption prevailing in most European countries was that gifted learners do not have any specific needs and thus do not need any special attention. It was believed that gifted learners would progress in regular classes on their own without further assistance. Gifted education was thus neglected. The issues of gifted pupils have increasingly gained ground in Europe in recent decades. In order to maximize the potential of gifted learners and make the gifted education sustainable, it is essential to improve flexibility of schools, to diversify teaching methods and techniques, to enrich the content of the curriculum and to increase the qualifications of the teachers who work with gifted learners.

To be specific, teacher training represents an area that is most neglected in spite of a general effort to improve the education of the gifted. Although there abounds a considerable number of research on sustainable teacher training programs for general education 
(Gadušová, Hašková, Malá, Munková, 2013, Flores, Santos, Fernandes, Pereira, 2014, Iliško, Skrinda, Mičule, 2014, Klímová, 2015, Pipere, Veisson, \& Salite, 2015, Gedžūne, 2015, Hanesová, 2015, Zygmunt, 2016) there is a limited amount of research done on sustainable teacher training programs for gifted pupils. A large-scale European wide research was conducted in 2005 (Monks, Pfluger, 2005), which provides information about the status and systems of gifted education in 21 European countries. However Slovakia did not participate in the research. The conducted research points out that only 9 out of 21 countries (Austria, Germany, Spain, Hungary, Luxembourg, the Netherlands, Romania, Slovenia and the United Kingdom) provide teacher training for those working with gifted pupils. In Europe we have a common language policy in the form of Common European Framework for Languages (2001), which determines concepts of foreign language teaching in European countries. Gifted education and teacher training of gifted pupils is so diverse in every country, so we believe that there should be in Europe at least some common principles on how to work with gifted pupils and requirements for teachers' qualifications with the aim to sustain the development of gifted children. Sterling (2008) emphasised that sustainable education moves towards deeper education itself including policies, purposes and practices. Education should sustain and realize human potential in relation to the need. There is a need to re-evaluate gifted education and teacher training concerning its existence and sustainability. This article presents information about the current state of teacher education for gifted pupils in Austria, Belgium, Finland and Slovakia with the focus on sustainability. The choice of these countries was purposeful as they offer very diverse understanding and system of gifted education and their systems of teacher training leads to a different level of sustainability of gifted education.

\section{The Training of Teachers for Gifted Children in Austria}

Austria is a country which has developed a nationwide gifted education program, including qualifications for teachers working with gifted children. Austrian legislation supports the education of gifted children via integrated instruction in traditional classrooms. This education takes the form of individual approach, acceleration, deepening of the curriculum, skipping a year, completing courses at a university and earlier enrolment into university. A segregated model of education is rare. Identification of gifted learners is carried out by teachers and psychologists who use standardized tests. Indicators for the identification of gifted learners are excellent academic results, which has not proven to be the most reliable indicators. (Oswald et al, 2005).

The training of teachers for gifted children in Austria is becoming increasingly topical. A large part of the curriculum at some faculties of education is aimed at gifted education. Universities provide lectures, seminars and workshops focused on theoretical and practical aspects of giftedness and gifted education. Faculties of education and educational institutes organize lectures and seminars for teachers within the scope of lifelong learning to ensure sustainability in their gifted teaching practice. Training of teachers for gifted learners emphasizes an inclusive approach; it trains future teachers for work with gifted pupils integrated into regular classes. OEZBF (Austrian Centre for Training and Research of Gifted Pupils) cooperates with faculties of education and universities in the curricula design of teacher training for gifted learners. They also 
cooperate in the development, implementation and evaluation of curriculum of teacher training for gifted learners at pre-school age (OEZBF, 2014). The topical nature of the issue of teacher training of the gifted pupils and the need for its sustainability resulted in the launching of a postgraduate training program for professionals in the education of gifted learners (e.g. a Master degree program for training of teachers for gifted children at the Danube University in Krems). Postgraduate education is possible at more than ten educational institutes; it is partially funded by the Ministry of Education and until 2005 more than 600 students graduated successfully (Oswald et al, 2005). The positive development in the field of gifted education is supported by the fact that educational standards, graduate programs, and particularly the White Paper in 2011 were established (White Paper Promoting Talent and Excellence). The White Paper is an extensive nationwide valid document which emphasizes the need for training of teachers for the gifted and specifies the education legislation at all levels - training of teachers for gifted children, system of education of gifted learners, etc. (Weilguny et al, 2011). The aim of the Austrian education policy is to provide at least one expert in the field of education of gifted pupils for each school. It is apparent that gifted education and adequate teacher training have become important issues of education in Austria and these can lead to great progress and sustainability of gifted education.

\section{The Training of Teachers for Gifted Children in Belgium}

Belgium is a case of a country, which delivers a totally opposite kind of approach to the education of the gifted. According to Kumpsa (2008) a long-term view has persisted in Belgium that the issue of giftedness is a luxury "nice to have" problem. Therefore Belgian legislation does not define giftedness or gifted education. However, the Ministry of Education has been involved in creating conditions for education of gifted pupils over the last decade, but still has not come to any decisions. There are no standards at the national level in Belgium which would determine the identification and subsequent education of gifted pupils. Schools have full autonomy and determine criteria for identification of and working with gifted pupils.

In Belgium, there are neither courses at faculties of education, nor compulsory disciplines aimed at gifted education. Teacher trainees can only attend optional courses focused on giftedness. University of Antwerp offers counselling to parents and teachers at the Centre for research of giftedness (Kieboom, 2005). With so little support of gifted children and lack of teacher training there cannot be any reference of sustainability of gifted education, as it virtually does not exist. There is however eagerness to improve this situation. For example, at a national conference in Belgium, organized by the Belgian association of professionals and parents of gifted children in 2011, the Minister of Education expressed the necessity of supporting gifted children and training of teachers for gifted children in the Belgian education system. Apart from earlier admission to school and skipping a year, there are no specific procedures and methods of gifted education and training of teachers for gifted children in Belgium. However Professor De Corte (in D'Hondt, 2012) came to conclusions that are now widely accepted. University teacher training requires much more attention in the field of gifted education and issues of giftedness should have a more prominent position in the Belgian school system. Otherwise, sustainable gifted education is not feasible. Just the opposite to the Austrian system of gifted education and teacher training, the Belgian system is underdeveloped. 
For the progress and sustainability of the gifted pupils, legislation changes, perception of the gifted, gifted programs and teacher training need to be made.

\section{Training of Teachers for Gifted Students in Finland}

Finland is a country with a specific system of education in general. Its gifted education is very different because it has no special status. Even though the Finnish legislation does not specify the gifted as learners with special educational needs, their pupils reach one of the best results in the world. The Finnish education system is strongly decentralized and only general guidelines are provided at national level. A specific feature of the Finnish education system is the recognition of the individual needs of all learners, differentiation of schools and school instruction according to the age and abilities of individual pupils. The schools provide individual training programs that enable differentiated learning process. The differentiated education represents a general policy of Finland and every learner (also gifted) benefits from the individualization of education. Learners are not marked and this fact allows them to accelerate according to their individual abilities. According to Tirri (2013) there are however some scholars in Finland who acknowledge the importance of recognizing the social and affective needs of gifted learners. Special schools, programs and summer camps for gifted children, which promote academic and creative giftedness of learners, are being organized.

In Finland there are not any programs aimed at educating gifted learners. In general, the qualification of teachers is based on individual interests and needs of learners. Current trends of differentiation and individualism are reflected in the possibilities of planning the curriculum and teachers are expected to find the most appropriate ways of developing the potential of all learners. Teacher trainees receive background information about giftedness and gifted learners as part of their study. The University of Helsinki and the University of Tampere provide courses for working with gifted pupils for in-service teachers according to their interests (Tirri, 2005). In spite of absence of legislation related to the gifted education in Finland, the education system (not only for gifted) operates as one of the best in the world. This system is clearly very efficient and Finland's results indicate great sustainability in all spheres of education, which is proved by top results in international testing. Finnish pupils achieve regularly the best results in international PISA testing out of all countries in the world (OECD, 2014).

\section{Training for Teachers of Gifted Students in Slovakia}

Slovakia was chosen because it is our home country and also has a specific system of gifted education. This system is compared with the previously mentioned systems. Slovak legislation (School Act no. 245/2008 $\$ 2$ letter j on education and training) defines a gifted learner as a child with special educational needs. Gifted children must be identified by centres of pedagogical-psychological advisory services. According to the Act 103 article 1 education of gifted learners is conducted in schools with a focus on the development of:

1. intellectual giftedness of children (general and intellectually specific giftedness)

2. the artistic giftedness of children

3. sport giftedness of children. 
Learners with a general intellectual giftedness (GIG) have a special state education program, but the principles are the same as those valid for other learners. However the education of pupils with a general intellectual giftedness has to consider the special educational needs in the form of appropriate forms, methods and techniques of teaching practice. Special schools or classes for children with a general intellectual giftedness (under Act no. 245/2008) are set up in Slovakia, after completion of the fifth year further study at a grammar school is expected. The educational process at schools for gifted learners is highly individualized. Learners may be reclassified into a higher grade, attend several grades at the same time, take some subjects from a higher grade, or they may have an individual learning plan. However, in general an expanding or enriching education is preferred. The maximum number of pupils per class is 12 . National curriculum (ŠKVP) allows schools to individualize the school curriculum and organisational forms of education for gifted learners. There are also special textbooks for Slovak language and mathematics available, which are used at the primary level of education for gifted learners (VÚDPaP, 2008). Moreover, education of gifted learners can take a form of integrated education in regular classes. In such case, an individual or group educational program is developed for integrated gifted pupils. Teachers in cooperation with an Institute for educational counselling and prevention are responsible for their development (Dock, 2005; Duchovičová, Babulicová, 2010). The system of gifted education in Slovakia is elaborated in a great detail and should guarantee sustainable gifted education.

However, the teacher training and qualifications of teachers of gifted learners do not have exact criteria and conditions. According to the national curriculum teachers of gifted pupils should meet the following qualification requirements: teaching qualification for primary level, or teaching qualification for specific subjects. Learners with GIG can be taught also by a university teacher or an expert with research experience/practice or special pedagogue. Teachers are chosen by the school director and they should be provided with special training for working with intellectually gifted learners. According to Páleník (2011) from Research Institute for Child Psychology and Pathopsychology (VÚDPaP) teachers in teaching practice are not prepared adequately for working with intellectually gifted learners and university education provides them only with minimum information on how to work with gifted pupils. The VÚDPaP has been focusing on the education of gifted children for over thirty years. VÚDPaP has included the issue of education of gifted learners into lifelong learning programs, particularly into the continuous education of teachers. The aim is to prepare primary school teachers for educational work with gifted children (Páleník, 2011). However, there are not any study programs aimed at training of teachers for gifted learners in Slovakia. Universities and faculties of education provide some courses designed for working with gifted children within the scope of academic subjects related to pedagogical and psychological matters, but the field didactics do not have to include issues concerning working with gifted learners. It depends on the individual universities and study fields whether they consider education of gifted learners necessary. The lack of teacher training in gifted education does not fit in with the elaborated system of gifted programs and the two together do not lead to sustainable education.

Teachers' qualification for working with intellectually gifted learners is at a low level. It is definitely an area that needs to be addressed. From the research, the existence of a special national curriculum and special classes for pupils with GIG, it is clear that the education of gifted children is a priority of the Slovak education system, but the 
actual teacher training is neglected. Even though Porubská proposed already in 1997 quite a detailed plan for teacher training of gifted children, in-practice teacher training is continuous education, there is not a noticeable improvement in gifted teacher training, which is considered as a problem and it needs to be dealt with. The only complex courses for teachers of gifted learners known to us are the training courses provided by VÚDPaP. Similarly to the VÚDPaP courses, universities, faculties of education, and methodological centres should be providing special courses and study programs for future teachers and in-practice teachers of gifted children. Master programs focusing on working with gifted children should be established at faculties of education and field didactics of particular major subjects should include working with gifted children. To reach progress and sustainability of gifted education, there is a great need to create and improve teacher training courses in the area of gifted education. Gifted children are the future of every country and therefore their education must not be neglected.

\section{Conclusion and Suggestions}

It is clear from this brief review of the issues of teacher training for gifted pupils that despite the great attention provided to the education of gifted pupils, the education of teachers of gifted learners has been neglected. Out of the mentioned countries, the training of teachers for gifted learners is firmly established and receives a considerable attention only in Austria. Austria is on the best path to gain progress and retain sustainability in teacher training and gifted education. Belgium is a country that has so far failed to address giftedness, gifted education, as well as teacher training for gifted pupils. Belgium is now at a starting point in the issue of gifted education. It appears that Belgium is still only finding ground in gifted education and there cannot be talk about sustainability of gifted education. Finland has long been one of the best in terms of education results in general, despite the absence of gifted education per se. It is likely due to the overall education system based on individual approach to learners, which is one of the specific features of working with gifted learners. Finland is one of the most successful countries concerning education in general and it has been gaining progress and sustainability in teacher training and education in general. Slovakia with elaborated gifted programs is missing programs in the area of teacher training for gifted pupils. The elaborated gifted programs and missing teacher training programs are in contrast and cannot succeed with the current system in ensuring sustainable gifted education. Scholars deal with topic giftedness (Porubská, 1997, Duchovičová, Babulicová, 2010, Veselá, 2010, Bírová, 2013, Reid, 2014, Kováčiková, 2015), but very little has been done in practice concerning training of teachers of gifted learners. For progress of the gifted pupils in special classes there needs to be courses provided not only in general pedagogy but also in the field of didactics with the aim to make gifted education sustainable.

There was a considerable review carried out by Reid and Boettger (2015), which analysed gifted education in ten European countries. The outcomes demonstrate a great variety in gifted education. With the aim to bring some system into understanding of gifted education, we recommend some common terminology, understanding, principles and requirements concerning gifted education in Europe. It would not be anything new in Europe, as European countries already share a common language policy (Common European Framework for Languages) which serves as recommendations for creating national curricula for foreign language learning in European countries. Similar policy 
could be applied in gifted education, which would bring unity in understanding gifted education and possibly its sustainability.

Concerning teacher training within the scope of academic subjects related to pedagogical and psychological matters, all faculties of education should offer courses on giftedness, peculiarities of gifted children, principles on working with the gifted, etc. What is definitely missing is training teachers in the field of didactics. This field includes working with pupils with special educational needs, but gifted are often avoided. Teachers and teacher trainees are experts in their subject matter (Soobik, 2014), but because the gifted children require special attention and have specific needs, the teachers need to be able to shift from the traditional approach towards the more constructivist approach and to adapt to differences of gifted children with the aim to reach sustainability of field didactics within gifted education.

At the university or institutional level, there is a need to create graduate and post graduate programs, courses in teacher training programs and courses for in-service teachers specialising on gifted education. Specialised courses should significantly contribute to sustainable gifted education, where sustainability is integrated into schools, classrooms, subjects, etc. (Redman, 2013). In service teacher trainings are very important for professional development of teachers, where they can not only escalate their knowledge, but also re-examine, re-evaluate their beliefs, which would lead them to self-reflective awareness (Kabadayi, 2016). This all should contribute to sustainable gifted education in practice (Iliško, 2007). The Austrian system of having specialists on gifted education in every school could be given as a model for sustainability of gifted programs in schools. It is common that schools employ special pedagogies, but their work focuses more on pupils with special educational needs in the form of learning disabilities, communication disorders, emotional and behavioural disorders, physical and developmental disabilities and gifted pupils' needs are neglected.

The paper includes research results gained as a part of the project APVV-15-0368 Prax v centre odborovej didaktiky, odborová didaktika v Centre praktickej prípravy.

\section{References}

Bírová, J. (2013). About theoretical definitions of pluralistic and pluricultural approaches. XLinguae, 6 (2), 91-103.

D’Hondt, C. (2012). Belgium. World Gifted Newsletter. 31 (2), 5. Retrieved from http://www.world-gifted.org/sites/default/files/WG122012.pdf

Dočkal, V. (2005). Zaměrěno na talenty, aneb, Nadání má každý. Praha: Nakladatelství Lidové noviny.

Duchovičová, J. \& Babulicová, Z. (2010). Possibilities for education of gifted pupils in integrated conditions as a way towards educational inclusion. In: Teacher training and development - scientific approach to didactics and method of teaching. Užice: University of Kragujevac.

Flores, M.A., Santos, P., Fernandes, S., Pereira, D. (2014). Pre-service teachers' views of their training: Key issues to sustain quality teacher education. Journal of Teacher Education for Sustainability, 16(2), 39-53. 
Gadušová Z., Hašková A., Malá E., Munková D. (2013) Technology of education: Terminology in use. Praha: Verbum.

Gedzune, G. (2015). Awakening pre-service teachers to childrenis social exclusion in the classroom. Discourse and Communication for Sustainable Education, 6(1), 95-109.

Hanesová, D. (2015). Searching of ways of effective plurilingual teacher trainees preparation. Slavonic pedagogical studies journal: the scientific educational journal, $4(2), 220-240$.

Iliško, D. (2007). Teachers as agents of societal change. Journal of Teacher Education for Sustainability, 7, 14-26.

Iliško, D., Skrinda, A., Mičule, I. (2014). Envisioning the future: Bachelor's and master's degree students' perspectives. Journal of Teacher Education for Sustainability, 16(2), 88-102.

Kabadayi, A. (2016). A suggested in-service training model based on Turkish preschool teachers' conceptions for sustainable development. Journal of Teacher Education for Sustainability, 18(1), 5-15.

Kieboom, T. (2005). Country specific information - Belgium. In: Monks, F.J., Pfluger, R. (ed.) Gifted education in 21 European countries: Inventory and perspective. Radboud University Nijmengen. Retrieved from https://www.bmbf.de/pub/gifted_ education_21_eu_countries.pdf

Klímová, B. (2015). Assessment in smart learning environment - a case study approach. Smart Innovation, Systems and Technologies, 41. Springer.

Kováčiková. E. (2015). Teaching English to learners with specific learnging needs. Teaching foreign languages to learners with special educational needs in Slovakia. 29-38.

Kumps, L. (2008). Effective advocacy for the gifted in Belgium. Understanding Our Gifted, 20(4), 8-12.

Lalinska, M. (2012). Posudenie cudzojazycnej kompetencie ziakov na vystupe z 1. stupna ZS v SR. XLinguae Journal, 5(4), 70-83.

Mönks, F.J. \& Pfluger, R. (2005). Gifted Education in 21 European Countries: Inventory and Perspective. Radboud University Nijmengen. Retrieved from https://www.bmbf. de/pub/gifted_education_21_eu_countries.pdf

OECD. (2014). PISA 2012 Results. Retrieved from http://www.oecd.org/pisa/ keyfindings/pisa-2012-results.htm

OEZBF. (2014). Professional Training of Teachers / Educators and Curriculum Development. The Austrian Research and Support Centre for the Gifted and Talented. Retrieved from http://www.oezbf.at/cms/index.php/professional-training-292.html

Oswald, F. et al. (2005). Country specific information - Austria. In: Monks, F.J. \& Pfluger, R. (ed.) Gifted education in 21 European countries: Inventory and perspective. Radboud University Nijmengen. Retrieved from https://www.bmbf.de/ pub/gifted_education_21_eu_countries.pdf

Páleník, L'. (2011). Edukácia intelektovo nadaných detí v základnej škole. Projekt programu špecializačného vzdelávania. Výskumný ústav detskej psychológie a patopsychológie. Retrieved from http://www.vudpap.sk/sk/kontinualne-vzdelavanie/.

Pipere, A., Veisson, M., Salite, I. (2015). Developing research in teacher education for sustainability: Un DESD via the journal of teacher education for sustainability. Journal of Teacher Education for Sustainability. 17 (2), 5-43. 
Porubská, G. (1997). Príprava učitel’ov pre prácu s nadanými žiakmi. In: Premeny výchovy $v$ škole a rodine. Nitra: UKF.

Reid, E. (2014). Challenges of teaching English to gifted children. Hradec Králové Journal of Anglophone Studies, 2(1), 104-113.

Reid, E., Boettger, H. (2015). Gifted education in various countries of Europe. Slavonic Pedagogical Studies Journal: The Scientific Educational Journal, 4(2), 158-171.

Redman, E. (2013). Opportunities and challenges for integrating sustainability education into k-12 Schools: Case study phoenix, AZ. Journal of Teacher Education for Sustainability, 15(2), 5-24.

Soobik, M. (2014). Teaching methods influencing the sustainability of the teaching process in technology education in general education schools. Journal of Teacher Education for Sustainability, 16(1), 89-101.

Sterling, S. (2008). Sustainable education - towards a deep learning response to unsustainability. Policy \& Practice. A Development Education Review, 6, Spring 2008, p. 63-68. Retrieved from http://www.developmenteducationreview.com/issue6perspectives 1

Tirri, K. (2005). Country specific information - Finland. In: Monks, F.J. \& Pfluger, R. (ed.) Gifted Education in 21 European Countries: Inventory and Perspective. Radboud University Nijmengen. Retrieved from https:/www.bmbf.de/pub/gifted_ education_21_eu_countries.pdf

Tirri, K. \& Kuusisto, E. (2013). How Finland serves gifted and talented pupils. Journal for the Education of the Gifted, 36(1), 84-96.

Van Tassel-Baska, J. (2013). The world of cross-cultural research: Insight for gifted education. Journal for the Education of the Gifted, 36(1), 6-18.

VÚDPaP - Výskumný ústav detskej psychológie a patopsychológie. (2008). Vzdelávací program pre 1. stupeň základnej školy pre žiakov so všeobecným intelektovým nadaním. Retrieved from http://www.vudpap.sk/sub/vudpap.sk/images/ISCED/ isced_1.pdf

Weilguny, W. et al. (2011). White Paper Promoting Talent and Excellence. Austrian Research and Support Center for the Gifted and Talented.

Ziegler, A., Stoeger, H., Harder, B. \& Balestrini, D.P. (2013). Gifted education in germanspeaking Europe. Journal for the Education of the Gifted, 36(3), 384.

Veselá, K. (2010). Role of creative writing in foreign language. Foreign language teaching and gifted and talented pupil. Brno. Masarykova univerzita, 184-194.

Zygmunt, T. (2016). Language education for sustainable development. Discourse and Communication for Sustainable Education, 7(1), 112-124.

Correspondence concerning this paper should be addressed to Mgr. Eva Reid, PhD. and doc. PhDr. BoženaHorváthová, PhD., Constantine the Philosopher University in Nitra, Faculty of Education, Dražovská 4, 94974 Nitra, Slovakia. Email: ereid@ukf.sk, bhorvathova@ukf.sk 